\title{
A new Bryde's whale (Balaenoptera edeni) record for mainland Portugal
}

\author{
Joana Castroo ${ }^{1,2}$, André Cid ${ }^{1}$ and Marina I. LABORDe ${ }^{1,2}$ \\ Contact email: jmadeiracastro@gmail.com
}

\begin{abstract}
The Brydes's whale (Balaenoptera edeni) is a species of baleen whale known to live year-round in warm waters. Here, we report the sighting of an adult individual during the summer of 2020 off the south coast of Portugal. The whale was observed 6.4 n.miles from the shore in water at a depth of $50.6 \mathrm{~m}$. Initially this individual was associated with a group of bottlenose dolphins. This is the first record of this species for mainland Portugal. The distribution of the species in the North Atlantic Ocean is still poorly known.
\end{abstract}

KEYWORDS: BRYDES'S WHALE; MOVEMENTS; ATLANTIC OCEAN; PORTUGAL; ALGARVE; NEW RECORD

The Bryde's whale (Balaenoptera edeni) is one of the less well studied rorqual species (Kato and Perrin, 2018; Maciel et al., 2018). Until recently its global conservation status was considered 'data deficient' but it is now classified as being of 'least concern'. Nevertheless, the global population trend remains unknown (Cooke and Brownell, 2018).

The taxonomy of the Bryde's whale has been in debate for some time (Mead, 1977; Rice, 1998). However, for the purposes of this note we consider the existence of a single species, Balaenoptera edeni, following the taxonomy adopted by Kato and Perrin (2009). In the Atlantic Ocean all Bryde's whales are believed to belong to the subspecies B.e. brydei (Kershaw et al., 2013; Society for Marine Mammalogy, 2020). However, a few authors contemplate two distinct species, $B$. edeni and $B$. brydei, the former being a smaller costal form found in the Indian and Western Pacific Oceans, and the latter a more oceanic form (Ho and Lanfear, 2010; Luksenburg et al., 2015). Historically, Bryde's whales were often misidentified as sei whales (Balaenoptera borealis), leading to an underestimation of the species from sightings (Freitas et al., 2012; Steiner et al., 2008). Additionally, the Omura's whale (B. omurai) was also considered a subspecies of Bryde's whale until as recently as 2003 when it was recognised as a distinct species.

Bryde's are the only baleen whale that live year-round in warm waters $\left(>16^{\circ} \mathrm{C}\right)$ (Kato and Perrin, 2009), approximately between $40^{\circ} \mathrm{N}$ and $40^{\circ} \mathrm{S}$ (Kato and Perrin, 2009; Shirihai et al., 2006). The distribution of the species in the North Atlantic Ocean is still poorly known (Cooke and Brownell, 2018; Kato and Perrin, 2009).

Very few records of sightings and strandings of Bryde's whales have been registered in the NE Atlantic Ocean. One stranded animal was recorded in Danish waters in 2000 (Kinze, 2006; Kinze et al., 2018) and another possible one on the German Baltic coast in 1944 (Kinze et al., 2011; Kinze et al., 2018).

In Portuguese territories, the Bryde's whale is frequently seen in waters around the Madeira Islands (southeast North Atlantic, $32^{\circ} \mathrm{N}, 17^{\circ} \mathrm{W}$ ) between the months of June and November (Alves et al., 2010). In the Azores, a Portuguese archipelago at higher latitudes (northeast North Atlantic, $38^{\circ} \mathrm{N}, 28^{\circ} \mathrm{W}$ ), the first sighting for this species was reported in 2004 (Steiner et al., 2008). Since then, it has been considered a regular visitor to these islands' waters during the spring and summer months (Silva et al., 2014). In continental Portugal, however, this note reports the first sighting of a Bryde's whale.

\footnotetext{
${ }^{1}$ AIMM - Associação para a Investigação do Meio Marinho, 1500-399 Lisboa, Portugal.

${ }^{2}$ MARE - Marine and Environmental Sciences Centre, Faculdade de Ciências da Universidade de Lisboa, 1749-016 Lisboa, Portugal.
} 
On 7 August 2020 at $10 \mathrm{~h} 52$ a Bryde's whale was observed 6.4 n.miles from the coast, southwest of Albufeira, on the south coast of mainland Portugal (Fig. 1). The sighting was registered by the AIMM - Marine Environment Research Association research team on board the research vessel Ketos, a $6.7 \mathrm{~m}$ long rigid hull inflatable. Photographs of the dorsal fin and body were collected using digital SLR cameras (Nikon D200 with a 70-300mm lens; Nikon D200 with an 18-200mm lens; Nikon D7100 with a 55-300mm lens) for species and photoidentification purposes.

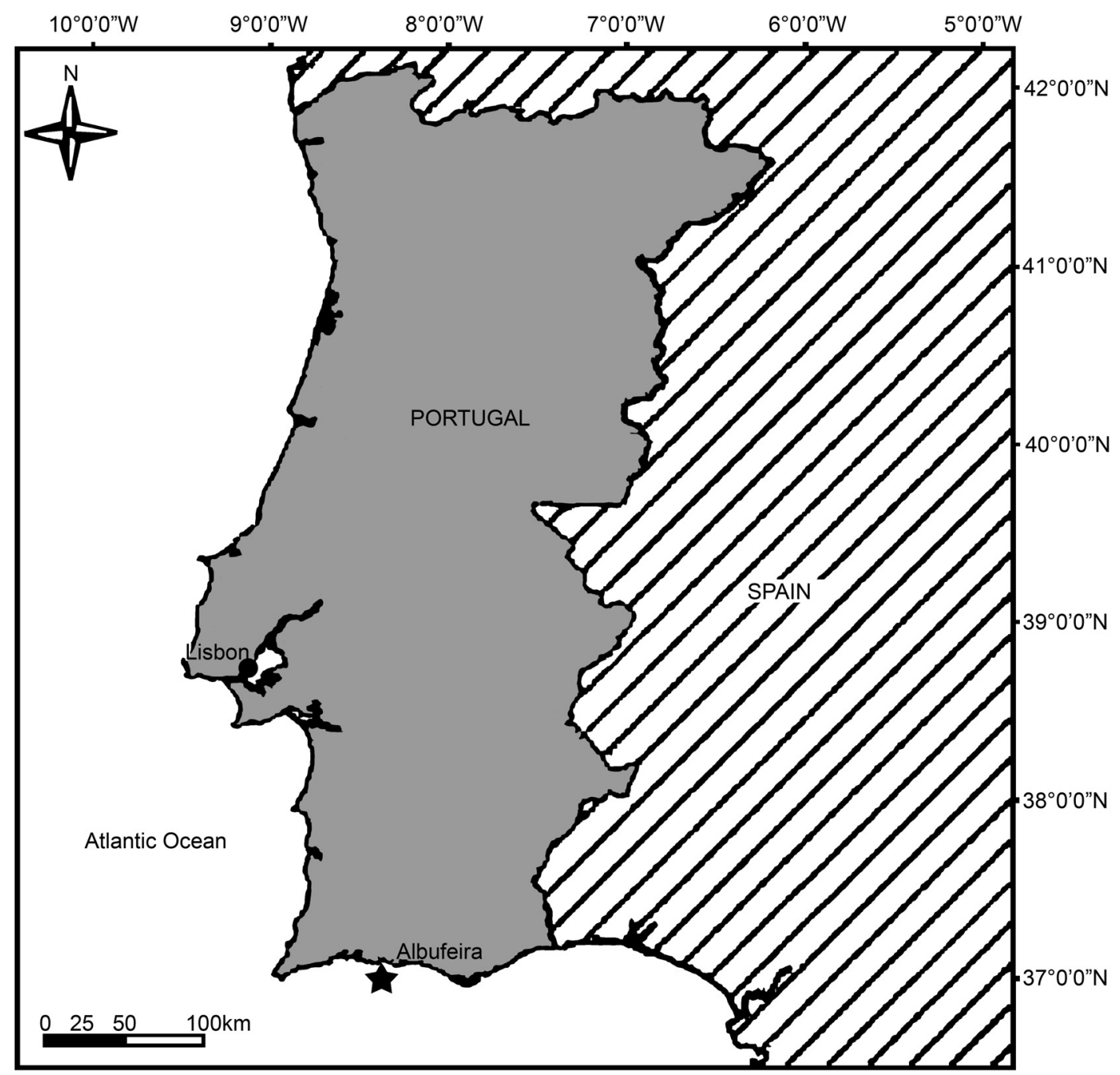

Fig. 1. Map of the geographical region with the location of the Bryde's whale sighting (black star symbol)

The sighting occurred in water at a depth of $50.6 \mathrm{~m}$ and sea surface temperature varied between 19.0 and $20.4^{\circ} \mathrm{C}$. The sea state was slight, with a Beaufort force between 3 to 4 , swell lower than $0.5 \mathrm{~m}$, poor visibility (less than $1 \mathrm{~km})$, no sun glare and no precipitation.

Only one adult whale was seen, estimated to be around $15 \mathrm{~m}$ in length.

The whale was observed during a sighting of bottlenose dolphins (Tursiops truncatus). This dolphin group was composed of 8-10 adult individuals performing deep dives. The whale suddenly emerged in the middle of the group while they were at the surface and continued to move in a westerly direction, while the group of dolphins kept moving south. The second blow of the whale was more than $50 \mathrm{~m}$ away from the group of dolphins. It was followed for 1 hour and 32 minutes for 8 n.miles in a westerly direction, approximately 6 n.miles from shore (Fig. 1). It was travelling at an average speed of 5 knots with a dive pattern of $1 \mathrm{~min} 30 \mathrm{~s}$. The animal blew only once after each dive. 


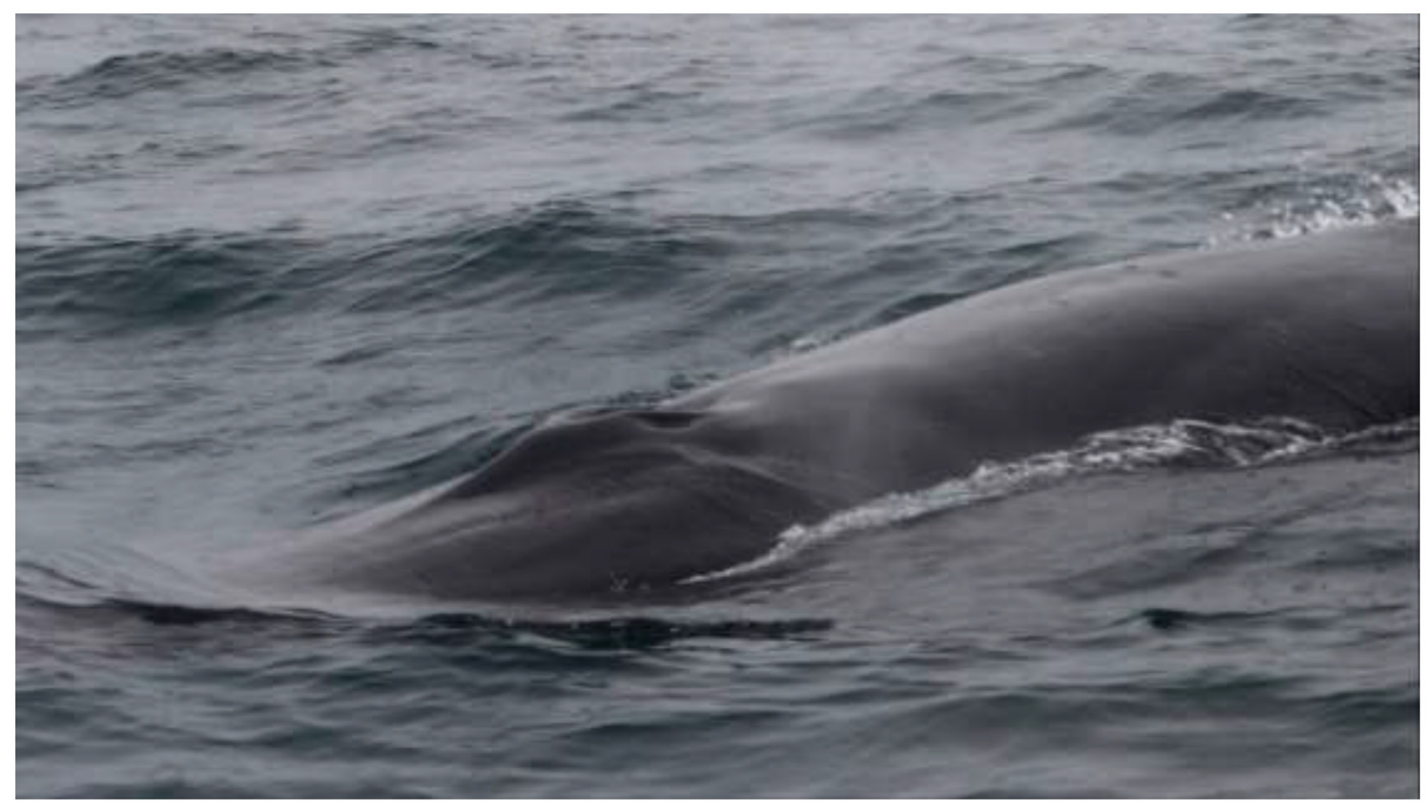

Fig. 2. Bryde's whale showing the three longitudinal ridges (Photos: AIMM, 2020).

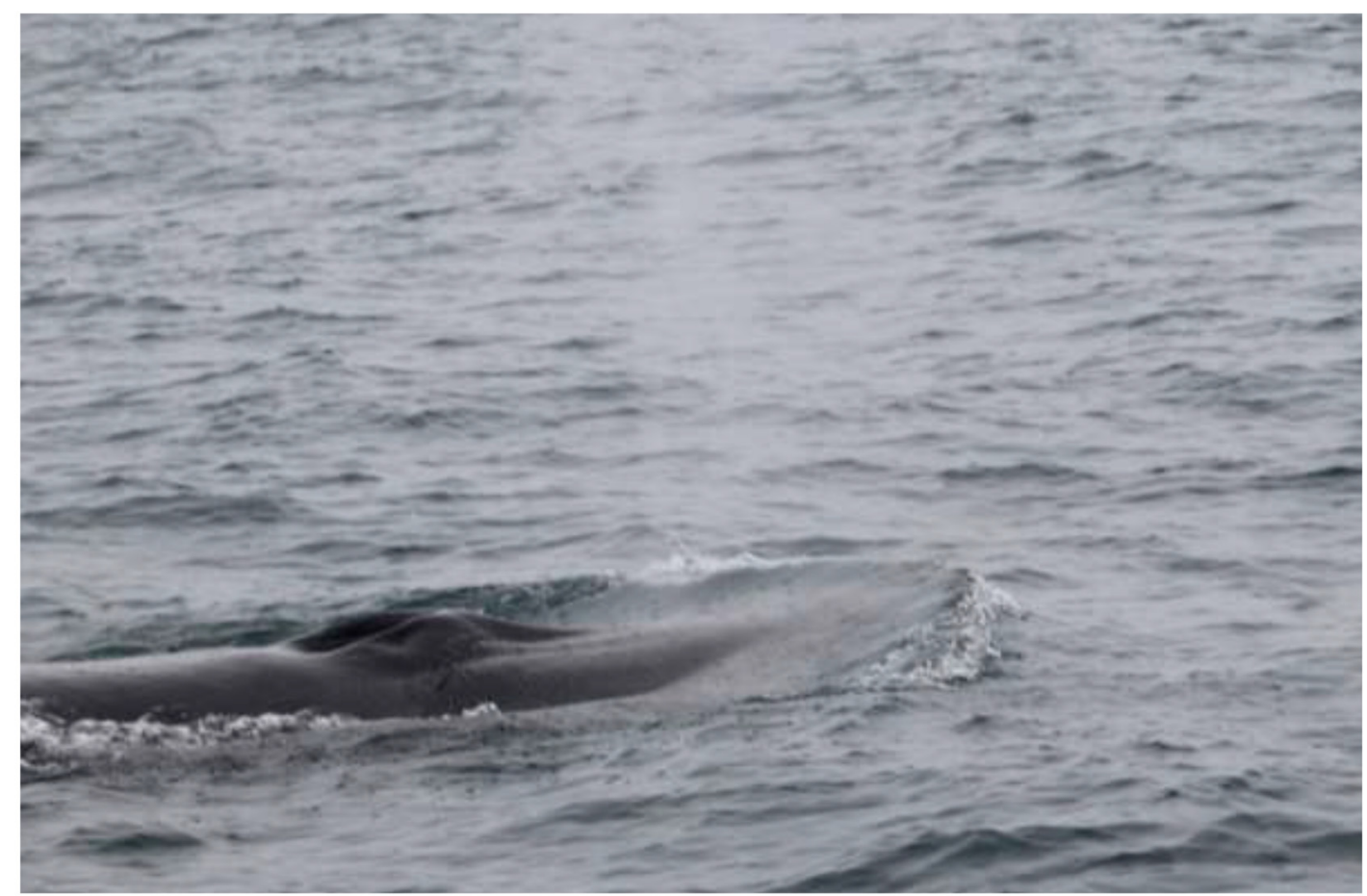

Fig. 3. Bryde's whale showing lateral sub-ridge that resembles more an indentation rather than a ridge (Photos: AIMM, 2020).

It was identified as a Bryde's whale by the presence of three longitudinal ridges along the rostrum and the flatness of the rostrum itself (Figs 2 and 3). In some photographs, these lateral sub-ridges on either side of the central ridge resemble more indentations rather than ridges. The size and shape of the dorsal fin resembled that of a Bryde's whale, although this feature alone is not conclusive for species identification (Fig. 4).

Bryde's whales have never been described off mainland Portugal before. The presence of Mysticeti in coastal waters of mainland Portugal is usually limited to rare encounters, except for minke whales (B. acutorostrata) that occur regularly (Bencatel et al., 2017). The south coast of Portugal is characterised by an intense wind-driven upwelling season from March to October and an upwelling system in the area of Cape St. Vincent (García Lafuente 
and Ruiz, 2007) making this an important region for cetaceans (Castro et al., 2020; Moura et al., 2012). During the summer months of 2020, the number of sightings of baleen whales along the south coast of Portugal was the highest in the past five years (22 sightings compared with an average of 10 sightings per year), with the majority of the sighted animals identified as minke whales (AIMM, unpublished data). It is possible that the high occurrence of these cetaceans is related to environmental changes (Anderwald et al., 2012; Hastie et al., 2005; Penry et al., 2011) such as sea surface temperature (Sasaki et al., 2013; Selzer and Payne, 1988) and prey availability (Maciel et al., 2018; Watanabe et al., 2012), although previous work indicated that Bryde's whale distribution is not closely related to water temperature and that this species has a wide temperature range (Kerosky et al., 2012; Steiner et al., 2008). It is thought that the abundance of this species is closely related to the upwelling systems that lead to higher rates of primary productivity (Maciel et al., 2018), and our study area appears to provide such conditions.

During this sighting, the whale was initially associated with bottlenose dolphins at a shallow bathymetry, which could indicate feeding. Previous studies have demonstrated that Bryde's whales have a preference to feed in shallow depths (Alves et al., 2010; Maciel et al., 2018) and that it is commonly associated with other species during feeding events (Penry et al., 2011). Nevertheless, it is important to note that during the reported sighting there was no evidence of feeding behaviour, neither from the whale nor the dolphins.

Another factor that could play a role in the elevated number of sightings of baleen whales in 2020 is that the presence of tourist boats (e.g. whale watching boats) was lower than normal during the months of May, June and July 2020, due to the COVID-19 pandemic. Several reports have been made about animals being seen more often in areas where they have previously disappeared and it has been suggested that marine animals might be moving more across the oceans due to lower levels of maritime traffic and noise-pollution (Rutz et al., 2020).

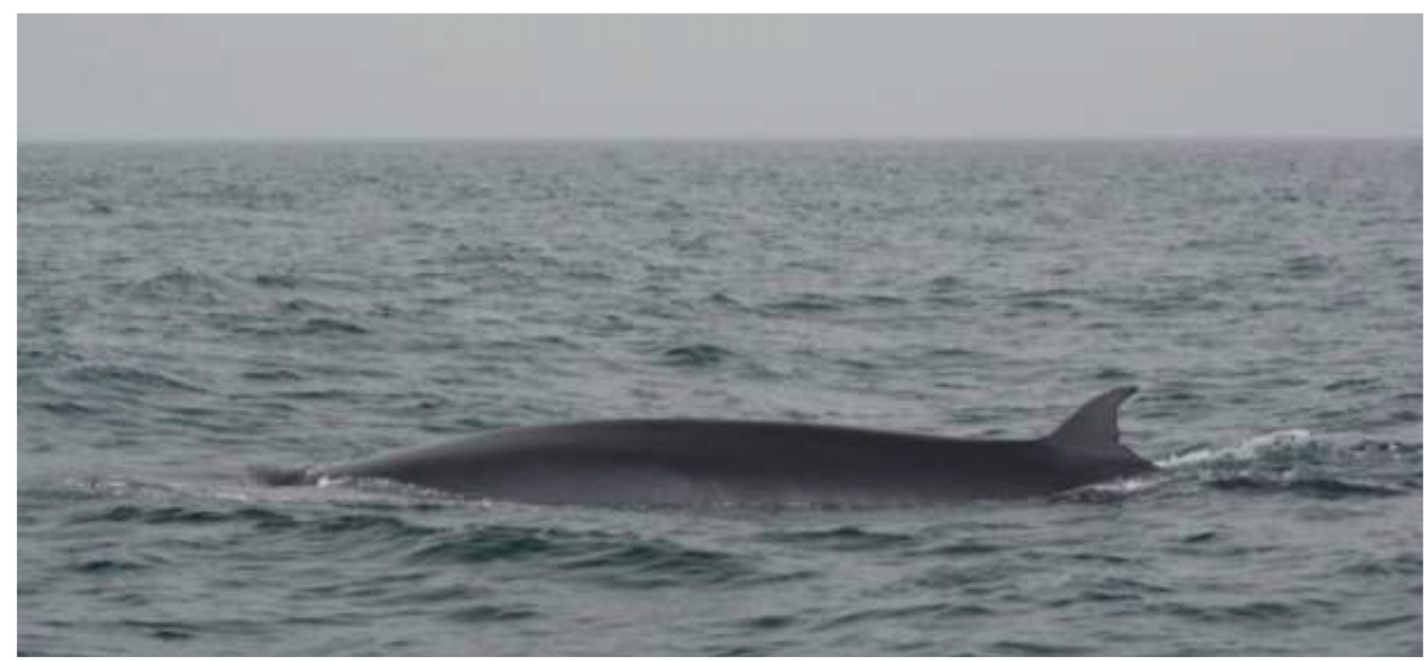

Fig. 4. Bryde's whale dorsal fin (Photos: AIMM, 2020).

This sighting represents a new record for Bryde's whale in mainland Portugal. The south of Portugal is an important region supporting considerable biodiversity (Lopes and Cunha, 2010) but only limited dedicated cetacean studies and surveys have taken place here because of financial and time constraints and the personnel required (Castro et al., 2020). It is essential to develop more scientific surveys in the region in order to have a better understanding of the cetacean diversity in the area.

\section{ACKNOWLEDGEMENTS}

The authors would like to thank all AIMM volunteers who participated in the data collection. We thank Henry Harper and Alicia Quirin for providing detailed comments that greatly improved this manuscript and general review. A particular thank you to Dr Gwenith Penry for her help with species identification. This research was funded by Associação para a Investigação do Meio Marinho (AIMM) and Fundação para a Ciência e a Tecnologia 
(FCT), through PhD grant to JC (SFRH/BD/134156/2017). The work was conducted under the authorisation of the Portuguese Conservation Institute (ICNF - AOC/30/2018). The authors have no conflicts of interest to declare.

\section{REFERENCES}

Alves, F., Dinis, A., Cascão, I. and Freitas, L. 2010. Bryde's whale (Balaenoptera brydei) stable associations and dive profiles: New insights into foraging behavior. Mar. Mamm. Sci. 26: 202-12. [Available at: $h$ ttps://doi.org/10.1111/j.1748-7692.2009.00333.x].

Anderwald, P., Evans, P.G.H., Dyer, R., Dale, A., Wright, P.J. and Hoelzel, A.R. 2012. Spatial scale and environmental determinants in minke whale habitat use and foraging. Mar. Ecol. Prog. Ser. 450: 259-74. [Available at: https://doi.org/10.3354/meps09573].

Bencatel, J., Álvares, F., Moura, A.E. and Barbosa, A.M. 2017. Atlas de Mamíferos de Portugal. Universidade de Évora. 356pp. [In Portugese].

Castro, J., Couto, A., Borges, F.O., Cid, A., Laborde, M.I., Pearson, H.C., Rosa, R., . 2020. Oceanographic determinants of the abundance of common dolphins (Delphinus delphis) in the South of Portugal. Oceans 1(3): 165-73. [Available at: https://doi.org/10.3390/ oceans1030012].

Cooke, J.G. and Brownell Jr, R.L. 2018. Balaenoptera edeni. The IUCN Red List of Threatened Species 2018: e.T2476A50349178. [Available at: $h$ ttps://dx.doi.org/10.2305/IUCN.UK.2018-1.RLTS.T2476A50349178.en Accessed 7. October 2020].

Freitas, L., Dinis, A., Nicolau, C., Ribeiro, C. and Alves, F.M.A. 2012. New records of cetacean species for Madeira Archipelago with an updated checklist. Bol. Mus. Munic. Funchal 62(334): 25-43.

García Lafuente, J. and Ruiz, J. 2007. The Gulf of Cádiz pelagic ecosystem: A review. progress in Oceanography 74(2-3): 228-51. [Available at: $h$ ttps://doi.org/10.1016/j.pocean.2007.04.001].

Hastie, G.D., Swift, R.J., Slesser, G., Thompson, P.M. and Turrell, W.R. 2005. Environmental models for predicting oceanic dolphin habitat in the Northwest Atlantic. ICES J. Mar. Sci 62: 760-70

Ho, S.Y.W. and Lanfear, R. 2010. Improved characterisation of among-lineage rate variation in cetacean mitogenomes using codonpartitioned relaxed clocks. Mitochondrial DNA 21(3-4): 138-46. [Available at: $h$ ttps://doi.org/10.3109/19401736.2010.494727].

Kato, H., Perrin, W.F., 2018. Bryde's Whale. pp.143-145. In: B. Würsig, J.G.M. Thewissen and K.M. Kovacs (eds). Encyclopedia of Marine Mammals (Third Edition). Elsevier, London. 1,190pp.. [Available at: https://doi.org/10.1016/B978-0-12-804327-1.00079-0].

Kato, H. and Perrin, W. 2009. Bryde's whales Balaenoptera edeni/brydei. Pp.158-63. In: W. Perrin, B. Würsig and J. Thewissen (eds). Encyclopedia of Marine Mammals (2nd ed.). Academic Press, Amsterdam, Netherlands.

Kerosky, S.M., Širović, A., Roche, L.K., Baumann-Pickering, S., Wiggins, S.M. and Hildebrand, J.A. 2012. Bryde's whale seasonal range expansion and increasing presence in the Southern California Bight from 2000 to 2010. Deep Sea Res. I: Oceanogr. Res. Pap. 65: 12532.

Kershaw, F., Leslie, M.S. and Collins, T. 2013. Population differentiation of 2 forms of Bryde's whales in the Indian and Pacific Oceans. J. Hered. 104: 755-64.

Kinze, C.C. 2006. Ny hval for Danmark: Brydeshval (Balaenoptera brydei) stranded ved Kyndby i lsefjord [A new whale in Denmark: Bryde's whale (Balaenoptera brydei) stranded at Kyndby in Isefiord]. Flora og Fauna 112: 61-6. [In Danish].

Kinze, C.C., Schulze, G., Skóra, K. and Benke, H. 2011. Zahnwale als Gastarten in der Ostsee. Meer. Mus 23: 53-82. [In German].

Kinze, C.C., Thøstesen, C.B. and Olsen, M.T. 2018. Cetacean stranding records along the Danish coastline: records for the period 20082017 and a comparative review. Lutra 61: 87-195. [Available at: https://zoogdierwinkel.nl/sites/default/files/imce/nieuwesite/ Winkel/pdf\%20download/Lutra\%2061(1)_Kinze\%20et\%20al_2018.pdf].

Lopes, F.C. and Cunha, P.P. 2010. A plataforma continental algarvia e províncias adjacentes: Uma análise geomorfológica. Ciências Geológicas - Ensino e Investigação e sua História 1(5): 479-89. [In Portugese].

Luksenburg, J.A., Henriquez, A. and Sangster, G. 2015. Molecular and morphological evidence for the subspecific identity of Bryde's whales in the southern Caribbean. Mar. Mamm. Sci. 31(4): 1,568-79. [Available at: $h$ ttps://doi.org/10.1111/mms.12236].

Maciel, I.S., Tardin, R.H. and Simão, S.M. 2018. Occurrence and habitat use of Bryde's whales (Balaenoptera edeni) in the Cabo Frio region, South-eastern Brazil. J. Mar. Biolog. Assoc. UK 98(5): 1081-86. [Available at: https://doi.org/10.1017/S002531541600134X].

Mead, J.G. 1977. Records of sei and Bryde's whales from the Atlantic coast of the United States, the Gulf of Mexico, and the Caribbean. Rep. Int. Whaling Commn. (special issue) 1: 113-16.

Moura, A.E., Sillero, N. and Rodrigues, A. 2012. Common dolphin (Delphinus delphis) habitat preferences using data from two platforms of opportunity. Acta Oecologica 38: 24-32. [Available at: https://doi.org/10.1016/j.actao.2011.08.006].

Penry, G.S., Cockcroft, V.G. and Hammond, P.S. 2011. Seasonal fluctuations in occurrence of inshore Bryde's whales in Plettenberg Bay, South Africa, with notes on feeding and multispecies associations. Afr. J. Mar. Sci. 33(3): 403-14. [Available at: https://doi.org/10.2989/ 1814232X.2011.637617].

Rice, D.W. 1998. Marine Mammals of the World: Systematics and Distribution. Special Publication Number 4, The Society for Marine Mammalogy. Allen Press, USA. ix+231pp.

Rutz, C., Loretto, M.-C., Bates, A.E., Davidson, S.C., Duarte, C.M., Jetz, W., Johnson, M., Kato, A., Kays, R., Mueller, T., Primack, R.B., RopertCoudert, Y., Tucker, M.A., Wikelski, M. and Cagnacci, F. 2020. COVID-19 lockdown allows researchers to quantify the effects of human activity on wildlife. Nat. Ecol. Evol. 4(9): 1,156-59. [Available at: https://doi.org/10.1038/s41559-020-1237-z].

Sasaki, H., Murase, H., Kiwada, H., Matsuoka, K., Mitani, Y. and Saitoh, S.I. 2013. Habitat differentiation between sei (Balaenoptera borealis) and Bryde's whales (B. brydei) in the western North Pacific. Fish. Oceanogr. 22(6): 496-508. [Available at: https://doi.org/10.1111/ fog.12037]

Selzer, L.A. and Payne, P.M. 1988. The distribution of white-sided (Lagenorhynchus acutus) and common dolphins (Delphinus delphis) vs. environmental features of the continental shelf of the northeastern United States. Mar. Mamm. Sci. 4(2): 141-53. [Available at: https://doi.org/10.1111/j.1748-7692.1988.tb00194.x]. 
Shirihai, H., Jarrett, B. and Kirwan, G.M. 2006. Whales, Dolphins and Seals: A Field Guide to the Marine Mammals of the World. A \& C Black Publishers Ltd., London. 384pp.

Silva, M.A., Prieto, R., Cascão, I., Seabra, M.I., Machete, M., Baumgartner, M.F. and Santos, R.S. 2014. Spatial and temporal distribution of cetaceans in the mid-Atlantic waters around the Azores. Mar. Biol. Res. 10(2): 123-37. [Available at: https://doi.org/10.1080/ 17451000.2013.793814].

Society for Marine Mammalogy. 2020. Committee on Taxonomy - List of marine mammal species and subspecies. [Available at: https://marinemammalscience.org/science-and-publications/list-marine-mammal-species-subspecies/. Accessed 16 February 2021].

Steiner, L., Silva, M.A., Zereba, J. and Leal, M.J. 2008. Bryde's whales, Balaenoptera edeni, observed in the Azores: a new species record for the region. Mar Biodivers. 1: e66. [Available at: $h t t p s: / / d o i . o r g / 10.1017 / S 1755267207007282]$.

Watanabe, H., Okazaki, M., Tamura, T., Konishi, K., Inagake, D., Bando, T., Kiwada, H. and Miyashita, T. 2012. Habitat and prey selection of common minke, sei and Bryde's whales in mesoscale during summer in the subarctic and transition regions of the western North Pacific. Fish. Sci. 78: 557-67. [Available at: $h$ ttps://doi.org/10.1007/s12562-012-0480-x]. 